\title{
Revisiting the Transition to Capitalism Debate
}

Resenha de: ANIEVAS, Alexander and NISANCIOGLU, Kerem. How the West Came to Rule: the Geopolitical Origins of Capitalism. London: Pluto Press, 2015. 375 pp.

Robin Blackburn*

University of Essex

Colchester - United Kingdom

This ambitious book covers over six hundred years of global history and offers a specifically 'geo-political' correction to a Marxist understanding of the emergence of capitalism. The book has extensive

* Robin Blackburn teaches at the New School in New York and the University of Essex, UK. He is the author of the The American Crucible (2011). E-mail: roblack@essex.ac.uk. 
chapters on the Mongolian Empires, the clash between Hapsburgs and Ottomans, the impact of the Black Death, the turn to slave plantations of the Americas and the profits of British rule in India. While developing a critique of traditional Marxist accounts, they uphold both Marx's concept of 'primitive accumulation' and what they call the 'classical' narratives of successive 'bourgeois revolutions', each helping to confirm a capitalist dynamic and the 'Rise of the West'. According to the 'consequentialist' doctrine they espouse the nature of revolutions is set by their results rather than their agents. The authors structure much of their narrative around a critique of 'Eurocentrism', which they see as conferring an unjustified salience and superiority on western institutions and a failure to register the weight of geo-political advantages and handicaps. The authors supply a new narrative that reworks the 'transition debate', Trotsky's theory of 'uneven and combined development' and a concept of the 'international' derived from International Relations, all of this from an avowedly 'anti-capitalist' standpoint.

The book develops a historical materialist approach but does not suppose that human history is an orderly march of successive modes of production, each born out of the contradictions of their predecessors. While their critique is welcome so is their refusal to throw out the baby with the bath water. The elaboration of theoretical models of social relations, and the identification of characteristic tensions within them, is an essential part of making sense of history. The book takes seriously the task of identifying the succession of structures and struggles that enabled capitalism to embody and promote increasingly generalized and pervasive commodification.

The authors argue that early capitalism was a more complex and global affair than is often allowed. Heteroclite labour regimes, and types of rule, gave rise to uneven and combined development in which the new and the old were closely interwoven. The authors often quote Marx's powerful passage from Capital, volume 1 chapter 31 sketching the successive moments of 'primitive accumulation', linked to gold and silver from the Americas, the Atlantic slave trade, slave plantations, trade wars, colonialism and so forth. New forms of plunder and super-exploitation punctuate later decades and centuries, with Western rule 
casting a long shadow. 'Primitive accumulation' was not just a passing phase but was stubbornly recurrent. It supplied would-be capitalists with the capital and labour force they otherwise lacked. The racialization of the enslaved and/or colonized generated an intermediary layer of 'free workers' that, if given slightly easier conditions, would become useful allies of the slaveholders, serving in their patrols and militias. Capitalist development, in this account, is invariably linked to racialization and super-exploitation, and is devoid of a progressive dimension.

The book's subtitle presumably supplies a key element of the answer to the question posed by the main title. The West's rise to global ascendancy is a team race which is won by Britain around 1763. (p. 272) The British win because their maritime-manufacturing complex is now turbo-charged by capitalism. While we may anticipate this conclusion much of the book's interest lies in the account it gives of how this point itself was reached.

The authors explain how Europe's mercantile and proto-capitalist elites exploited the toilers of the 'East' but they grant that it can also sometimes be thought of as the global 'North' exploiting the global 'South'. While the East and South were mercilessly plundered they contributed to the rise of the West in other ways too.

Anievas and Nisanancioglu - henceforth AA and KN - urge that in preceding epochs the Mongolian empires created relatively peaceful conditions along the Silk Road and in adjacent areas which were consequently favorable to the revival of Western commerce in the Baltic and Mediterranean. The nomad's military prowess inspired emulation. They observe: 'The Mongol Empire also facilitated the diffusion of such key military technologies as navigational techniques and gunpowder from East Asia to Europe all of which were crucial to Europe's subsequent rise to global pre-eminence... The Mongols would acquire such techniques in one society and then deploy them in another...' (p. 73). We can agree that these exchanges were highly significant without seeing those involved as capitalists.

The authors urge that the hugely destructive Mongol invasions of China led its rulers to abandon their projects of expansion and to 
stand down the voyages of Admiral Zheng He's mighty fleet. As Joseph Needham used to insist, China made an outstanding contribution to the science and material culture of the West. AA and KN remain focused mainly on the geopolitical and do not concern themselves with Needham's "Grand Titration".

It is fascinating to consider what would have happened if Chinese sailors and merchants had made contact with the Americas before the Europeans. Admiral Zheng He repeatedly sailed to the Indian Ocean but neglected the Pacific. If he had turned left rather than right, and sailed to the Americas, China might have been able to pre-empt Columbus and Cortes, especially when it is borne in mind that a silver famine was asphyxiating the Chinese economy at this time. A Chinese mercantile colony in Central America would have thrived on the exchange of silk fabrics and porcelain for silver. The Aztec and Inca rulers would, perhaps, have been able to strengthen their defenses with Chinese help (and gunpowder) and repulse Spanish attempts to conquer the 'American' mainland. (China did not go in for overseas territorial expansion).

$\mathrm{AA}$ and FN confer great importance on the bonanzas of American silver and gold arguing that the differential use made of precious metal plays a key role in explaining the great divergence between West and East. ( p. 248-9) But they and the authorities they quote do not explain how the silver and gold were extracted and refined, processes that fit their mixed labour model because it involved tribute labour and wage labour but fell short of a capitalist dynamic because the indigeneous miners had to spend most of their earnings on buying food and clothing from the royal shops that were kept supplied with these essentials of life in the mountains from the tribute goods which the Spanish overlords secured from the native villages. This closed circle of production and consumption led to output of thousands of tons of silver, with the royal authorities taking the lion's share but did not promote capitalist accumulation.

In their own accounting for the divergence between East and West they cite the 'indispensable' work of Jack Goody (p. 304, footnote 22) 
but do not take sufficient account of his stress on differences concerning family form and the regulation of kinship. Goody maintained that clans and kin accumulated so much power in the East that they weakened the state's power to tax and regulate. In Goody's view this challenge to the power of kinship was a Western European phenomenon and was driven by the material interests of the Catholic Church. (The Development of the Family and Marriage in Europe, 1988). This interesting line of thought has not received the attention it deserves from historical materialist accounts, including How the West Came to Rule. Whether it is right or wrong, it points to a level of analysis of social reproduction that should figure in any materialist account.

AA and KN eschew speculative 'counter-factuals', but they do claim a positive role for Asian empires despite the latter's often-tight mercantilist policies. They have little time for the argument of some global historians that the land-based empires of Asia briefly encouraged trade only to strangle its autonomous momentum by over-regulating and over-taxing it. Ellen Wood has argued in The Empire of Capital (2004) that the geographical fragmentation of Europe allowed for the rise of sea-borne empires whose merchants became more difficult to control. But for $\mathrm{AA}$ and $\mathrm{KN}$ the empires were already highly diverse and made their own qualitative input to the rise of Western capitalism through a multitude of dispersed influences and contributions.

Thus the rise of the Ottomans issued a powerful check to European expansion and tied them down in the Balkans, the Adriatic, the Levant and North Africa. According to AA and KN this blockage to the East allowed the western Europeans to seize their chance in the Americas and to initiate a new type of global trade: 'By blocking the most dominant European powers from their customary conduits to Asian markets, the Ottoman's directly compelled then to pursue alternative routes.' (p. 115). However this free-floating compulsion was only compelling because of the breakthrough of a new and more intense - now capitalist - consumerism.

The authors do give importance to Dutch and English trading patterns and to what they call 'company capitalism', the state chartering 
of companies to trade with the East and West Indies. They see these companies as dominating the English and Dutch maritime economy of the $17^{\text {th }}$ and $18^{\text {th }}$ century (p. 116). They urge that the Dutch were constrained by the fact that they were reliant on Ottoman sources for cotton and other vital raw materials for their textile manufacturing. (p. 117) The English eventually prevail because they are less exposed to continental warfare than the Dutch.

The geographic advantages conferred by England's relative 'isolation' from the continent enabled it to outflank its rivals. (p. 116). They conclude: 'English development in the sixteenth century can best be understood as a particular outcome of "combined development" [...] Ottoman geopolitical pressure must therefore be seen as a necessary but not sufficient condition for the emergence of agrarian capitalism in England.' (p. 119) The causality embraced by the authors in these passages is a weak one whether addressing the impetus to trade, England's 'isolation' or the authors' exaggerated view of 'company capitalism'. Indeed the turn to the Americas should be seen as a having two distinct waves, firstly the silver surge of the mid and late $16^{\text {th }}$ century while allowed Europe to buy Eastern spices and silks and, secondly, the rise of the sugar and tobacco plantations of the Americas, which really belongs to $17^{\text {th }}$ century and after. It was not until the early $17^{\text {th }}$ century that Dutch and English merchant adventurers turned to setting up plantations to meet the popular demand for sugar and tobacco, discovering that this offered far larger returns than either the Eastern trades or preying on Spanish fleets. At first these plantations were worked by free, European youths but demand was so buoyant that the merchants brought African captives who had greater immunity to tropical diseases and brought valuable agricultural skills. The Dutch West and East India companies played a role in this because they blazed a trail for English and French planters. Once the Dutch had lost Angola, Brazil and New Amsterdam, their operations became a side-show.

How the West Came to Rule pushes the debate about the transition to capitalism into new areas and that is itself salutary. The geo-political perspective yields new insights. But the argument from geo-political necessity to economic novelty moves too rapidly and insists that 
the emergence of capitalism in England has no primacy in the switch from luxury trades to building slave plantations (this gruesome primacy should be a source of national shame not pride).

As already mentioned, the Eastern trade was largely confined to small quantities of expensive luxuries in the $16^{\text {th }}$ and $17^{\text {th }}$ centuries. The Dutch and English $17^{\text {th }}$ century interlopers and marauders, with their contempt for Spanish mercantilism, pioneered the large scale Atlantic trade in items of popular consumption. Before long the European companies were left far behind and the free-lance slave traders, privateers and smugglers became the champions of laissez faire and free trade, and became thoroughly respectable.

Sugar and tobacco, the new popular pleasures, came to Europe not from Asia but from Brazil, Barbados and Virginia. The surge of plantation development was initiated by 'New Merchants' not by the official trading companies. The chartered trading companies played a very modest role because they embodied the backward practices of feudal business, with its royal charters. By contrast the New Merchants favoured a much looser variety of mercantilism that allowed for competition and innovation. Whereas the companies were looted by their own management, the 'New Merchants' kept a close eye on their investments. The initiatives of the new merchants stemmed from a surge of commodification and domestic demand, itself the product the spread of capitalist social relations in the English countryside as well as towns. Tenant farmers, improving landlords, lawyers, stewards, and the swelling ranks of wage labourers, had the cash or credit to buy these popular treats and indulgences. Without the forced labour of the plantations, and Hobsbawm's 'forced draught' of consumer cash, these trades would not have kindled the $18^{\text {th }}$ and $19^{\text {th }}$ century blaze of the hybrid Atlantic economies. AA and $\mathrm{KN}$ do register the plantation revolution but insist that it would be wrong to see English capitalism and wage labour as a 'prime mover'.

How the West Came to Rule has a good chapter on the slave plantations and their massive contribution to capitalist accumulation in the long $18^{\text {th }}$ century. But $\mathrm{AA}$ and $\mathrm{KN}$ do not concede that the planta- 
tions were summoned into being by the cash demand generated by the world's first revolutionary capitalism. They underplay the role of the New Merchants (and their captains and seamen) with their double role as entrepreneurs and political leaders. This was the epoch of the English Civil War and 'Glorious Revolution'. The classic work on the New Merchants stresses their link to England's transition to capitalism is Robert Brenner's Merchants and Revolution (1993). One might have thought that Brenner's work would be grist to the mill so far as AA and KN are concerned. However the reader of How the West Came to Rule is repeatedly warned not to be misled by Brenner's account of capitalist origins and development (see especially pp. 22-32, 118-9, 279-81 amongst many others).

$\mathrm{AA}$ and FN contest the novelty and centrality that Brenner accords to the spread of capitalism and commodification in $16^{\text {th }}$ and $17^{\text {th }}$ century rural England. They see instead a long chain of 'value added' contributions from colonial or semi-colonial Asia, Africa and the Americas, all helping to bring global capitalism into existence. They concede to Brenner 'the great merit of de-naturalising the emergence of capitalism' (p. 81) but dispute the idea that this remarkable new twist in human history was the unintended result of a three-way struggle between English landlords, tenant farmers and landless labourers as he argued in his now-classic articles in Past and Present and New Left Review in the 1970s and 1980s. Brenner did not himself always connect his decisive research into the New Merchants with the so-called 'Brenner thesis'. Nevertheless he identified the crucial break-through, showing that agrarian capitalism developed from landlords who demanded money rents, tenant farmers needed cash to pay rent, and landless rural workers, who had to sell their labour power if their families were to be housed and fed. Farmers who needed or wanted to pay for extra hands had an incentive to seek labour-saving innovations. The wages and fees paid by employers would also helped to swell the domestic market, encouraging commodification. Since agriculture accounted for at least $70 \%$ of GDP its transformation had great consequences.

Jan de Vries argues that early modern Europe was gripped by an 'industrious revolution' reflecting a more intense labor regime and a 
proto-capitalist consumerism. A taste for tobacco, sugar, coffee and cotton apparel encouraged many into new habits premised upon the increasing importance of the wages, rents, profits, fees and salaries of an Anglo-Dutch 'market revolution' in the years 1550-1650. Shakespeare's The Tempest (1614) gives us a glimpse of the feasting and rebellions that early modern capitalism, with its visions of plenty, could inspire and of the varieties of enslavement it entailed. By the mid-19 ${ }^{\text {th }}$ century daily life had been re-shaped by sweetened beverages, jam, confectionary, washable clothes, colourful prints and the chewing or smoking of tobacco.

$\mathrm{AA}$ and KN decry what they term the 'ontological singularity' of Brenner's economic logic, urging that it leads to a reductionism that has no space for race or patriarchy. They argue that 'patriarchy and racism' are 'not external to capitalism as a mode of production but constitutive of its very ontology.' (p. 278). It is difficult to see how any account could be more reductionist than one which simply (con)fuses capitalism with racism and patriarchy. Nevertheless there are interesting questions which arise here. Could capitalism survive if deprived of the fruits of gender and racial exploitation? There are certainly feminists and anti-racists who believe that much can be achieved short of the total suppression of capitalism - and there are some who believe that better versions of capitalism could assist in promoting feminist and anti-racist goals. The spectrum here was illuminated by Nancy Fraser's Fortunes of Feminism (2014).

Back in the day the more radical British and US abolitionists campaigned courageously for racial justice and equality in the name of a 'free labour' or forty acres and a mule, demands compatible with capitalism. Socialists might be happy to form alliances for progressive goals to be achieved 'by any means necessary and appropriate'. If we grant the theoretical possibility that patriarchy and racism could be suppressed but capitalism remains, this outcome might still prove to be undesirable, impractical and unstable. The intimacy of the connections between capitalism, racism and patriarchy suggest that they could share a common fate, though other outcomes are quite possible. 
$\mathrm{AA}$ and $\mathrm{KN}$ endorse the classic claim that the rise of capitalism was given needed extra-momentum by a series of 'bourgeois revolutions'. Their account of the main revolutions is not detailed but adds the dialectical sweep of their story. AA and KN quote Anatolii Ado to the effect that 'the popular revolutions of the petty producers ought to be seen as an essential element of the capitalist dynamic'. (p. 212). Slave resistance sometimes took the form of demanding wages while itinerant peddlers happily bought 'stolen goods' from the slaves.

While I find AA and KN's sketch of the bourgeois revolutions makes for a more complex account, there is still a way to go. The American War of Independence led to the destruction of the European colonial empires in the Americas. This was a mighty blow for capitalism in the Atlantic societies and helped to trigger the French Revolution and hence the Haitian revolution. The further impact on Spanish America and Brazil are not discussed. All these events echoed themes of bourgeois revolution and the 'rights of man' as re-worked by free people of colour, slave rebels, liberty boys, dockers, sailors and the 'picaresque proletariat'. The black Jacobins denounced the 'aristocracy of the skin'. AA and KN could, perhaps, have drawn on their notion of a mixed social formation to consider in more depth the worlds of indios, caboclos, petty producers, runaways, store keepers, itinerant peddlers and the 'sans culottes of the Americas'. The bourgeois character of these revolutions in the end excluded as many as it aroused.

How the West Came to Rule offers so much that it would not be fair to dwell on its omissions. The American Revolution tests the limits of the model advanced by AA and KN. The North American farmers and merchants have a solid claim to have defied and destroyed mercantilism and colonial subjection. But the planters were not exactly bourgeois and the indigenous peoples and the enslaved Africans found no solace and much suffering and bitterness in the extraordinary rise of the White Man's Republic. In this as in other cases the initial impact of bourgeois revolution was to stimulate the plantation trades rather than weaken slavery or racialization. 
How the West Came to Rule $(H W C R)$ rightly stresses the massive 'Atlantic' contribution to the development of capitalism in the $17^{\text {th }}$, $18^{\text {th }}$ and $19^{\text {th }}$ centuries. Whether it is Britain, France, Spain, or even Portugal and the Netherlands, the volume of trade that was bounded by the Atlantic was very much greater - down to about 1820 - than Europe's trade with the East. Of course after that date British rule in India, and the sub-continent's commerce, became far more important for the metropolis, and the same could be said for Indonesia and Dutch rule. Whereas the spice trade to Asia required two or three galleons a year in the $16^{\text {th }}$ century the plantation trade was to require thousands of ships by the mid $19^{\text {th }}$ century. AA and KN maintain that Britain's early industrialisation was based on Indian inputs (p. 246). In fact England's $18^{\text {th }}$ century cotton manufacturers looked to the Caribbean and Anatolia for most of their raw material. It was not until the $19^{\text {th }}$ century that India became Britain's main source of cotton and the captive Indian market a major outlet. AA and $\mathrm{KN}$ could have dwelt at greater length on the hugely destructive impact of British rule in India - famines, fiscal exactions, de-industrialization and so forth - but they do explain the Raj's success in building a locally-financed and recruited Army of India and alliance with the subcontinent's 'martial races'. British India troops held down the widening boundaries of the Raj and were deployed to many parts of the empire. They formed part of the British forces that invaded China in 1839-42, 1859-62 and 1900. (p. 263) This was the true apogee of empire. But the rapacious ultra-imperial unity of the Western powers and Japan did not last for long, leading, as it did, to a new epoch of war and revolution.

How the West Came to Rule addresses a large and complex question in interesting new ways and is to be commended for that. It draws on wide reading and demonstrates the continuing relevance of the debates on the transition to capitalism and gives them a geographically and conceptually wider scope. While their account may be open to objection at various levels their choice of topic and the breadth of their approach is timely and welcome.

Recebido: 26/07/2017 - Aprovado: 10/08/2017 